\title{
МЕТОДИЧКИ ПРИСТУП ТЕМИ СЛОВЕНСКОГ ЈЕЗИКА И ПИСМА У ХАЗАРСКОМ РЕЧНИКУ МИЛОРАДА ПАВИТА НА ДОДАТНОЈ НАСТАВИ У СРЕДњОЈ ШКОЛИ
}

\begin{abstract}
АПСТРАКТ: У раду је представљен методички модел за анализу теме језика и писма старих Словена (словенског језика и писма) у Хазарском речнику Милорада Павића на додатној настави у четвртом разреду средње школе. Реализација модела замишљена је кроз четири наставна часа. На првом часу тема словенског језика и писма пореди се са чињеницама у историји језика и књижевној традицији. На другом часу се, применом концептуалне анализе (користећи појмовне метафоре), разматра начин на који су словенски језик и писмо представљени у Хазарском речнику. Трећи и четврти час посвећени су интерпретацији уочених метафора у контексту композиције и поетике Хазарског речника и постмодернизма уопште. Кроз реализацију модела ученици се сусрећу са важним постмодернистичким појмовима и темама (текст, интертекстуалност, енциклопедичност, итд.), истовремено обнављајући постојећа знања из историје језика и књижевности.
\end{abstract}

Кључне речи: словенски језик и писмо, Хазарски речник, Милорад Павић, постмодернизам, настава српског језика, настава књижевности, додатна настава.

\section{METHODOLOGICAL APPROACH TO THE LANGUAGE AND ALPHABET OF THE EARLY SLAVS IN MILORAD PAVIĆ'S DICTIONARY OF THE KHAZARS IN TEACHING ADDITIONAL CLASSES IN HIGH SCHOOL}

ABSTRACT: In this paper we present a methodological model dedicated to the analysis of the language and alphabet of the early Slavs (= Slavonic language and alphabet) in Milorad Pavić's Dictionary of the Khazars - for students of additional classes in a high school (the fourth degree). The realization of the model assumes four lessons. The first one is dedicated to the comparison of the way the Slavonic language and alphabet are presented in Dictionary of the Khazars to the facts known from history of language and medieval

1 Рад представља измењену верзију семинарског рада писаног у оквиру курса Методика наставе српског језика - специјални курс, којим руководи проф. др Драгана Вељковић Станковић, на мастер програму Српски језик на Филолошком факултету Универзитета у Београду у школској 2016/17. години. Све евентуалне грешке ауторова су одговорност. 
literature. The second lesson discusses the way(s) the Slavonic language and alphabet are conceptualized in the Pavić's novel, using conceptual metaphors to conduct the analysis. The third and the fourth lessons are dedicated to the interpretation of excerpted metaphors according to the composition and poetics of Dictionary of the Khazars, and postmodernism in general. By implementing the model students are supposed to learn about many important concepts and topics in postmodernism (text, intertextuality, encyclopedism, etc.), at the same time renewing the existing knowledge about history of both language and literature.

Keywords: language and alphabet of early Slavs, Milorad Pavić, Dictionary of the Khazars, postmodernism, teaching Serbian language, teaching literature, additional classes.

\section{0. УВОД}

У раду представљамо методички модел за обраду теме словенског језика и писма у Хазарском речнику Милорада Павића на часовима додатне наставе у четвртом разреду средње школе. Пре него што се осврнемо на мотивацију за избор ове теме и наставне циљеве које желимо да постигнемо, укратко ћемо образложити синтагму словенски језик, као једну од централних тема у раду. Овај назив користи се у Хазарском речнику и за говорни/народни језик старих Словена и за њихов први књижевни језик, који је данас у науци познат као старословенски, старочрквенословенски или црквенословенски језик. У томе Павић следи традицију, будући да су и Константин и Методије први књижевни језик Словена називали словенским језиком (Поповић 1999: 65). Стога и ми у раду употребљавамо назив словенски језик за оба наведена варијетета, користећи атрибуте говорни, односно књижевни да међу њима нагласимо разлику тамо где је то потребно.

Мотивација за овај рад је вишеструка. Историји језика прилази се из другог угла - она се прелама кроз призму ученицима необичног постмодерног дела, чиме се и сама, на неки начин, реактивира и онеобичава. Истовремено, активирају се и ученичка знања из средњовековне књижевности и културне историје кроз интеракцију са основним постмодернистичким темама и идејама, са којима су се ученици први пут срели у завршном разреду средње школе. У методичком моделу који предлажемо одлучили смо се, наиме, да тему словенског језика и писма посматрамо пре свега у светлу структуре и поетике Хазарског речника и поетике постмодернизма уопште. Тако ученици, осим што обнављају знање о словенском језику, ћирилици, глагољици, Ћирилу, Методију итд., упознају појмове попут интертекстуалности, енциклопедичности, идеју доживљаја света као текста и друге појмове и теме важне за постмодерно доба. Тиме се прати однос између језика, књижевности, историје и културе, између различитих књижевних епоха, лингвистике и теорије књижевности.

Образовни циљеви који се остварују кроз реализацију понуђеног модела јесу обнављање и продубљивање знања из историје језика и књижевности, обнављање стечених и стицање нових знања о Хазарском речнику М. Павића и поетици постмодернизма. Ученици ће кроз одабране 
мотиве и теме, анализом делова текста, продубљивати знање о композицији и поетици Хазарског речника неким важним појмовима и терминима постмодерне поетике (текст, интертекстуалност, фрагментарност, енциклопедичност у науци и књижевности). Ученици на овај начин, такође, продубљују знање о појмовним метафорама.

Један од васпитних циљева који се остварују предложеним моделом јесте развијање свести о важности традиције, успостављања чврстих веза између традиције и модерног доба, старог и новог. Посебно је важно и развијање критичке свести, на коју Хазарски речник уопште, па и кроз тему словенског језика и писма, указује, кроз позив на уважавање разноликости и туђег мишљења - на уважавање и других и друкчијих „истина”. На ширину знања и развијање енциклопедијског духа упућују не само различите области које се моделом обухватају - језик, књижевност, историја, култура, итд. - већ и сам појам енциклопедичности, који заузима важно место у анализи.

Кроз повезивање градива и успостављање аналогија између различитих области, различитих мотива на микро и макро плану, ученици се оспособљавају да и у другим сферама - анализи других дела, других језичких тема, па и у другим областима, као и активностима у непосредној животној пракси, поступају на једнако иновативан начин. Ученици ће бити у могућности да критичко размишљање о језику, књижевности и историји примене и у реалном животу, у коме су свакодневно изложени идеолошки обојеним дискурсима. У томе видимо испуњење функционалних циљева које реализација одабраног модела може да понуди.

Пре него што изложимо сам модел, укратко ћемо образложити његову композицију. Реализација модела замишљена је кроз четири наставна часа. Први час одговара на питање шта? - на њему се разматра однос тематике словенског језика и писма у Хазарском речнику према историји језика и књижевној традицији. Други час одговара на питање како? - применом појмовних метафора анализира се начин на који су словенски језик и писмо представљени у овом Павићевом књижевном остварењу. Трећи и четврти час одговарају на питање зашто? - на њима се оно што је претходно запажено анализира у контексту структуре и поетике Хазарског речника и постмодерне књижевности.

\section{1. ПРВИ НАСТАВНИ ЧАС - СЛОВЕНСКИ КЬИЖЕВНИ ЈЕЗИК И ПИСМО У КОНТЕКСТУ ИСТОРИЈЕ И ТРАДИЦИЈЕ}

Пошто су се са историјом словенског језика и писма ученици упознали у ранијим разредима (основне и средње школе), настава на додатној настави може почети поређењем познатих чињеница са њиховим представљањем у Хазарском речнику. Пре почетка првог часа ученици добијају задатак да пажљиво прочитају одреднице посвећене Ћирилу и Методију у Хазарском речнику. Уз то, једна група ученика добија задатак да се подсети основних 
чињеница из историје језика (читањем литературе коју припреми наставник ${ }^{2}$ ), док друга група ученика чита Ћирилово и Методијево житије (за ову прилику довољно је подсетити се само одломака посвећених моравско-панонској мисији) $)^{3}$. Ученици посебну пажњу треба да обрате на следеће: друштвено-историјски контекст (зашто се јавила потреба за стварањем књижевног језика Словена); статус словенских писама (хронологија, творци, а у житијима и како је описан настанак писма); улога грчког језика и алфабета. На основу предочених истраживачких задатака, ученици запажају сличности и разлике између науке, књижевне традиције и света књижевног дела (Хазарског речника).

Најсажетије речено, наука каже да је кључну улогу у настанку првог словенског књижевног језика имала религија: старословенски језик настао је за потребе богослужења на матерњем језику Словена (због чега су Ћирило и Методије долазили у сукоб са тзв. тројезичницима, тј. заговорницима тезе да се вера сме исповедати само на три језика: латинском, грчком и хебрејском). У науци је устаљено мишљење да је глагољица старије словенско писмо, те да је њен творац Константин (Ћирило), који је имао помоћ свог брата Методија. Ћирилица је млађе писмо, чији су творци ученици Солунске браће. Познато je, такође, да је глагољица вероватно најпре називана ћирилицом. За настанак ћирилице недвосмислен значај имао је грчки алфабет, а у богаћењу апстрактног лексикона грчки језик (исп. и Станишић 2004, Грковић-Мејџор 2007, Николић 2002: 18-21). Са друштвено-историјским аспектом настанка књижевног језика Словена ученици се сусрећу и кроз житија - у њима се говори о мотивима настанка, описује се „борба” са тзв. тројезичницима, помиње се држање литургије на словенском језику, итд. За средњовековну књижевну традицију карактеристичан је топос чињења чуда. Тако ученици и кроз Ћирилово житије могу видети да је настанак писма приказан као божански дар: Ћирило слова ствара уз помоћ божанске милости. Треба напоменути и следећу чињеницу, на коју нас подсећа В. Станишић (2004: 384): иако се у словенској писмености од најстаријих времена употребљавају два писма (глагољица и ћирилица), током читавог средњег века у старословенској књижевности говори се о јединственом словенском писму, чији је творац Ћирило.

У делу су ове чињенице ,разложене” кроз две приче: једну бисмо могли назвати параболом о припитомљавању дивљег језика, а другу

\footnotetext{
${ }^{2}$ На пример, рад Марка Поповића (1999) или Јасмине Грковић-Мејџор (2007), који су написани на занимљив и ученицима пријемчив начин. Разуме се, наставник може препоручити и другу литературу по свом избору.

${ }^{3}$ Модел који представљамо не подразумева детаљно поређење Хазарског речника са средњовековном књижевношћу (в. Радуловић 2006 за такав приступ), па се пажња не посвећује, на пример, опису Ћириловог детињства, сараценској и хазарској мисији већ је фокус на словенском језику и писму.
} 
Даубманусовом причом о настанку ћирилице. Парабола о припитомљавању дивљег језика наслања се на научне чињенице на следећи начин: стварање словенског књижевног језика стављено је у контекст религије и борбе са тзв. тројезичницима; наглашено је грчко посредништво; уважена је чињеница да су створена два писма - прво глагољица, затим ћирилица. Представљањем Солунске браће, Ћирила (и Методија), као твор(а)ца оба писма - ова прича излази из оквира науке, ослањајући се на књижевну традицију (која подразумева јединственог творца писма). У том смислу, ова је прича „хибрид” науке и књижевне традиције:

А потом је дошла још једна опсада града чије је име носио. Док су Словени 860. опседали Цариград, Константин је на малоазијском Олимпу правио у тишини монашке ћелије замку за њих - градио прва писмена словенске азбуке. Први пут је начинио обла слова, али словенски језик је био толико диваљ да мастило није могло да га задржи, па је начинио другу азбуку од решеткастих слова и у њих је затворио тај непокорни језик, као птицу. Касније, када је припитомљен и када је научен грчком (јер језици уче друге језике), словенски језик се могао ухватити у она првобитна, глагољска писмена... (s. v. „Ћирило”, Павић 2012: 97-98) ${ }^{4}$.

Са следбеницима и ученицима браћа су 867. године кренула на једно од оних путовања где је сваки корак слово, свака путања реченица, а сваки застој број у великој књизи. У Венецији су 867 . ушли у нову расправу с тријезичницима, а потом су стигли у Рим ${ }_{[,]}$где је папа Хадријан II прихватио учење солунске браће као исправно и рукоположио словенске ученике у цркви Св. Петра. Тамо је том приликом појана словенска литургија на језику који тек што је био укроћен и са балканских ширина сапет допремљен у престоницу света као животињица у кавезу глагољских писмена (s. v. „Методије Солунски”, 67-68).

Даубманусова верзија усаглашенија је са сликом из књижевне традиције: говори се о јединственом писму (ћирилици) и јединственом творцу (Ћирилу, коме помаже брат Методије). И овде је наглашено грчко посредништво. Према О. Радуловић (2006: 283), стварање писма приказано је као чињење чуда, што је у складу са средњовековном поетиком. ${ }^{5}$ Читамо следећи одломак.

${ }^{4}$ Надаље у тексту подразумева се исто издање, па наводимо само име одреднице и бројеве страница.

${ }^{5}$ Говорећи о лику Ћирила у Хазарском речнику, А. Татаренко (2013: 191) најпре примећује да Павић приповеда о значају традиције и о личном (Ћириловом) доприносу стварању словенских писмена, лишавајући легенду компоненте чудесног. Нешто касније (idem: 193) ова ауторка ће истаћи: „Ново читање легенде - одузимање причи о Ћирилу „чудесних” момената, традиционалних за житије - резултат је утицаја постмодерног доба, када се као најфантастичнија показује реалност, а извор чудесног постаје сам човек”. Међутим, ако извор чудесног постаје човек, онда ни сама 
Даубманус преноси овакву причу о настанку словенске азбуке. Језик варвара никако се није хтео укротити. Једне брзе тронедељне јесени седела су браћа у ћелији и узалуд покушавала да испишу писмена која ће се касније звати ћирилицом. Посао им није полазио за руком. Из ћелије видела се лепо половина октобра и у њему тишина час хода дуга и два широка. Тада је Методије скренуо пажњу брату на четири крчага која су стајала у прозору њихове ћелије, али споља, с оне стране решетака.

- Да су ти врата забрављена упитао је. Константин је разбио један од крчага, унео крхотине део по део кроз решетку у ћелију и ту поново саставио у целину крчаг лепећи га пљувачком и глином с пода испод својих ногу. Тако су урадили и са словенским језиком, разбили га на парчад, унели га кроз решетке ћирилских слова у своја уста и улепили крхотине својом пљувачком и грчком глином испод својих табана... (s. v. „һирило”, 98).

Ученици се подстичу да запажања до којих су дошли представе на прегледан начин и размисле о уоченим разликама. Запажене сличности и разлике могу се представити, на пример, помоћу три круга - који ће представљати науку, књижевну традицију и Хазарски речник - тако што ће се у сваком од њих бележити запажене чињенице, а у њиховим пресецима заједничке особине. Наведене активности се одвијају кроз сарадњу наставника и ученика (на основу запажања до којих су дошли упоредним читањем текстова посвећених историји језика, односно читањем житија и одговарајућих одредница у Хазарском речнику).

Кроз поређење статуса словенског језика и писма у историји језика, књижевној традицији и Хазарском речнику ученици упознају појам интертекстуалност, један од најзначајнијих појмова у постмодерном добу. Интертекстуалност се дефинише као особина текста заснована на његовој унутрашњој повезаности са другим текстовима. Значење текста се, дакле, образује кроз однос према другим текстовима, чиме се сугерише постструктуралистичко схватање да ниједан текст није самосталан ни фиксиран, већ променљив, а његов смисао се стално изнова конструише (Popović ${ }^{2}$ 2010: 296-297). Или, по речима У. Ека (2008: 513), „[...] knjige uvek govore o drugim knjigama i svaka priča pripoveda neku već ispripovedanu priču". Како истиче теоретичарка постмодернизма Л. Хачион (1996: 261), интертекстуалне природе су и текстови историје, а не само књижевни текстови. Приче о словенском језику у Павићевом роману, видели смо, у

легенда не може бити лишена чудесног, већ се мења извор тога чудесног: то није више Бог, већ човек. Можемо додати да је ово у складу са целокупном поетиком Хазарског речника, у коме улогу демијурга преузима човек, покушавајући да текст претвори у тело (Бранковић ствара Петкутина; његов циљ, као и циљ многих других ликова у роману, јесте оваплоћење Адамовог тела на земљи). 
интертекстуалној су вези и са историјским (тј. историјскојезичким) текстовима и са књижевним текстовима.

Ученицима треба скренути пажњу на чињеницу да интертекстуалност као поступак постоји практично откад постоји и књижевност, али да је сам појам и термин посебно значајну улогу добио у 20. веку (прва га је употребила J. Кристева, уп. Popović ${ }^{2} 2010$ : 295-296), нарочито међу постструктуралистима и постмодернистима. ${ }^{6}$

Следеће проблемско питање јесте зашто су дате две верзије приче о настанку словенског језика и писма, које се при томе међусобно разликују по односу према науци и књижевној традицији. Један од могућих одговора поетички произилази из саме структуре Павићевог дела: то је роман, дакле кьижевно дело, али роман у облику лексикона, који претендује да се представи као научан и веродостојан (уз навођење референци на крају одредница).

На крају првог часа ученици добијају истраживачке задатке за наредни час. Први час је био посвећен томе како се информације предочене у Хазарском језику односе према чињеницама из историје језика и средњовековне књижевности. Други час посвећен је начину презентовања чињеница. Стога ученици добијају задатак да размисле о томе како су словенски језик и писмо представљени у Павићевом роману: да ли се о њима извештава неутрално, у складу са научним стилом, или експресивно, у складу са књижевноуметничким стилом. Треба да издвоје све изразе који им се чине необичним и занимљивим.

\section{2. ДРУГИ НАСТАВНИ ЧАС - КОНЦЕПТУАЛИЗАЦИЈА СЛОВЕНСКОГ ЈЕЗИКА И ПИСМА}

Ученици ће као занимљивости у представљању словенског језика и писма вероватно запазити следеће: то што се словенски језик пореди са дивљом птицом, то што се говори о припитомљавању језика, прављењу замке у коју треба ухватити словенски језик и сл. Закључиће да се о словенском језику и писму не говори научним, већ књижевноуметничким стилом.

Позната је човекова потреба (и нужност) да апстрактне и непознате појмове представи и разуме преко конкретнијих и познатијих. У свакодневном говору, на пример, често говоримо о времену као о новцу (Немој да ми трошиш време!), о животу као путовању (Корачајући кроз живот, стижемо до краја живота), итд. Сличним средствима служимо се и у науци - говоримо о корену речи, гранама лингвистике, синтаксичким

${ }^{6}$ Ово се испоставља веома важним. Из наставне праксе бележимо овакав пример. Један ученик имао је задатак да се позабави појмом маркираност у језику. Док је извештавао о значају Р. Јакобсона за овај појам, саопштио је да маркираност у језику није постојала док је Јакобсон није „измислио”. 
стаблима, итд. Метафорама се, дакле, користимо да апстрактни свет око себе разумемо и представимо. Књижевноуметнички стил ове механизме, који су део нашег мишљења, користи као основу, али метафоричке појмове и слике обогаћује многим детаљима, повезујући притом, на оригиналан начин, неке наизглед не тако блиске домене (исп. и Klikovac 2004). Стога се концептуална анализа намеће као погодна да се на прегледан начин представи како се словенски језик и писмо у Хазарском речнику доживљавају. Претпоставка за овакву врсту анализе јесте да су ученици на часовима лексикологије већ упознати са појмовним метафорама и основама концептуалне анализе (што се предлаже у методичкој литератури, в. нпр. Вељковић Станковић 2011).

Говорећи о појмовној метафори у књижевној анализи (тј. као средству когнитивне поетике $)^{7}$, П. Стоквел набраја следеће стилистичке могућности за метафоричку реализацију (почев од најексплицитнијих ка мање експлицитним): сличност, аналогија и проширена метафора (Мозак је као град. Његови старији делови окружени су догађајима који су се касније развили); копулативне конструкције (Мозак је град); апозиције и други паралелизми (Мозак, преплашени град...); партитивни (генитивни) изрази (Ha улицама и угловима мога ума..); преобликовање (урбани мозак 'мислећи град'); сложенице и лексички амалгами (метромозак < метро + мозак); реченична метафора (Ово је нервни центар тела) ${ }^{8}$; фикција и алегорија (наратив у коме су психоаналитички архетипи представљени као градска обележја и становници) (Stockwell 2005: 107-108). Овде су наведени (прилагођени) Стоквелови примери (већина њих илуструје метафору МОЗАК ЈЕ ГРАД), али се појмовних метафора ученици на почетку часа могу подсетити и кроз концептуализацију неких у свакодневном говору уобичајених апстрактних појмова (какви су време, љубав, срећа и сл.). Затим се приступа анализи прича о словенском језику и писму. Ради прегледности, али и касније интерпретације, парабола о припитомљавању дивљег језика и Даубманусова прича о настанку ћирилице могу се анализирати засебно.

На основу израза запажених у тексту, ученици уз наставникову помоћ формулишу метафоре и указују на конкретна места у тексту на основу којих су до тих метафора дошли. Метафоре се са изразима из текста могу повезати тако што се у заграду иза сваке метафоре наведу речи и реченице које на такву метафору упућују, или тако што се метафора и њој одговарајући израз означе истом бојом. На основу анализе, метафоре из параболе о припитомљавању дивљег језика могу се формулисати, на пример, на следећи начин:

\footnotetext{
${ }^{7}$ Наравно, оваква се анализа наслања на општу теорију појмовних метафора (в. нпр. Lakoff \& Johnson 1980/2003, Klikovac 2004).

${ }^{8}$ Мисли се на типичне случајеве кад се појмовна метафора може уочити тек на нивоу целе реченице. Овде се именицом центар успоставља веза са градом.
} 
САСТАВЉАЮЕ АЗБУКЕ ЈЕ ПРАВЉЕЮЕ/ГРАЪЕЊЕ ЗАМКЕ;

АЗБУКА (ГЛАГОљИЦА/ЋИРИЛИЦА) ЈЕ КАВЕЗ;

СЛОВЕНСКИ (ГОВОРНИ) ЈЕЗИК ЈЕ ДИВЉА ПТИЦА/ЖИВОТИЬА;

СТВАРАЬЕ КЬИЖЕВНОГ ЈЕЗИКА ЈЕ ПРИПИТОМЉАВАҢЕ/КРОЋЕЊЕ ДИВЉЕГ ЈЕЗИКА;

СОЛУНСКА БРАЋА СУ ПУТНИЦИ КРОЗ ЈЕЗИК/ТЕКСТ.

Метафоре из Даубманусове приче о настанку ћирилице могу се представити овако:

СЛОВЕНСКИ (ГОВОРНИ) ЈЕЗИК ЈЕ ДИВЉА ЖИВОТИЬА;

СЛОВЕНСКИ (ГОВОРНИ) ЈЕЗИК ЈЕ КРЧАГ КОЈИ СЕ МОЖЕ РАЗБИТИ;

ЋИРИЛИЦА ЈЕ КАВЕЗ/ЗАТВОР;

СТВАРАњЕ ЋИРИЛИЦЕ ЈЕ УНОС РАЗБИЈЕНОГ ЈЕЗИКА КРОЗ РЕШЕТКЕ СЛОВА И ЊЕГОВО ЛЕПЉЕЊЕ;

ПЉУВАЧКА СОЛУНСКЕ БРАЋЕ И ГРЧКА ГЛИНА СУ ЛЕПАК ЗА СПАЈАҢЕ КЬИЖЕВНОГ ЈЕЗИКА СЛОВЕНА.

Као што ове две приче имају и сличности и разлике у односу према науци и књижевној традицији, и њихово представљање се донекле подудара, а донекле разликује (на пример, заједничко је представљање словенског језика као дивљег, односно азбуке као кавеза). Занимљиво је приметити како се у концептуализацији писма Павић поиграва облицима слова: облом глагољицом и, у контрасту са њом, решеткастом ћирилицом (која стога може „послужити као кавез”).

На крају другог часа ученици добијају упутства за наредни час, на коме се интерпретирају метафоре уочене у параболи о припитомљавању дивљег језика. Треба да размисле о томе како се уочене метафоре могу интерпретирати у контексту поетике и структуре самог Хазарског речника (и шире, поетике постмодернизма). Конкретније - зашто би азбука била кавез? зашто је словенски језик потребно припитомити? зашто би „прављење” књижевног језика могло бити замка? зашто Ћирило и Методије путују кроз текст? Ученици се упућују и на читање одговарајућих одломака Хазарског речника у којима се говори о томе како папагаји (типично припитомљене птице, које обитавају у кавезу) преносе хазарски језик, што би могло подстаћи на размишљање о значају кавеза и припитомљавања, као и у одговарајуће одломке у којима је и живот других јунака представљен као „утекстовљени пут". 


\section{3. ТРЕЋИ НАСТАВНИ ЧАС - ОД КОНЦЕПТУАЛИЗАЦИЈЕ КА ИНТЕРПРЕТАЦИЈИ (1)}

На трећем часу дискутује се о уоченим метафорама у параболи о припитомљавању дивљег језика. Ове се метафоре пре свега доводе у везу са важном постмодернистичком темом доживљаја света као текста. Наводимо их опет ради лакшег праћења:

САСТАВЉАЬЕ АЗБУКЕ ЈЕ ПРАВЉЕЊЕ/ГРАЪЕЬЕ ЗАМКЕ;

АЗБУКА (ГЛАГОљИЦА/ЋИРИЛИЦА) ЈЕ КАВЕЗ;

СЛОВЕНСКИ ЈЕЗИК ЈЕ ДИВЉА ПТИЦА/ЖИВОТИЬА;

СТВАРАЬЕ КЬИЖЕВНОГ ЈЕЗИКА ЈЕ ПРИПИТОМЉАВАЮЕ/КРОЋЕЬЕ ДИВЉЕГ ЈЕЗИКА;

СОЛУНСКА БРАЋА СУ ПУТНИЦИ КРОЗ ЈЕЗИК/ТЕКСТ.

Ако слова схватимо као основне нити од којих је саткан сваки текст, онда азбуку можемо посматрати кроз метонимијску везу са текстом (АЗБУКА ЗА ТЕКСТ) - нарочито у контексту Хазарског речника, чије су одреднице поређане управо по азбучном реду. Стварање словенског књижевног језика, које је нераскидиво повезано са стварањем азбуке, може значити улазак у текстуализовану историју - односно, у оне делиће историје до којих можемо доћи (само) тумачењем текстова. С обзиром на то да нам је прошлост доступна само у траговима, никада ни приближно у целини спознатљива (што је једна од основних постмодернистичких премиса, в. Нас̌ion 1996), сваки покушај њеног обуздавања, кроћења, припитомљења - кроз фиксирање у тексту - мора представљати замку у коју смо осуђени да непрестано упадамо покушавајући да прошлост рашчивијамо. Азбука (= текст) је, дакле, кавез од ознака које теже да делић прошлости заточе и пренесу га кроз векове, по цену да њихова означена стално измичу кроз решетке, опомињући нас да се над прошлошћу непрестано замишљамо. Нешто друкчије осмотрено, (текстуализована) историја је кавез, а (недоступна) прошлост је слобода. Парадоксално, како се чини, слобода је дата само као наговештај, ка њој се мора гледати кроз решетке (званичне) историје.

Солунска браћа, која су тај „кавез” направила, и сама су његови заточеници: „Са следбеницима и ученицима браћа су 867. године кренула на једно од оних путовања где је сваки корак слово, свака путања реченица, а сваки застој број у великој књизи” (s. v. „Методије Солунски”, 67). Њихово представљање у складу са постмодернистичким топосом света као текста у Павићевом роману само нас подсећа на то да су наша знања о Ћирилу и Методију и иначе текстуализована, доступна тек на основу неколиких средњовековних списа (као што су читава историја и стварност посредовани текстом). Наравно, нису Солунска браћа једини који воде текстуализовани живот. Помоћу ове метафоре повезују се главни ликови у сва три временска слоја у Црвеној књизи, као што је приказано следећим цитатима (први говори о Авраму Бранковићу, а други о др Суку): 
Хронологија Бранковићевог живота и деловања најбоље се васпоставља на основу писане исповести коју је пећком патријарху послао из Пољске други писар Аврама Бранковића, и на основу једне житејне иконе с чудима Св. Илије пророка, јер је Бранковић свакој сцени из живота свога светитеља прилагођавао збивања свога живота и бележио о томе податке на полеђини слике (s. v. „Бранковић Аврам”, 34-35).

Мислио је како та зграда личи на неку књигу писану непознатим језиком, који није још савладао, ти ходници на реченице туђег језика, а собе на стране језике које никада није чуо (s. v. „Сук др Исајло”, 82).

У цитату посвећеном др Суку запажа се метафора ЈЕЗИК ЈЕ ГРАЂЕВИНА, која се природно саодноси са метафором ПУТОВАњА КРОЗ ТЕКСТ/ЈЕЗИК. Та грађевина, заправо, највише подсећа на лавиринт (уп. непознати језик који Сук није савладао, стране језике које није чуо), па бисмо је прецизније могли формулисати као ЈЕЗИК/ТЕКСТ ЈЕ ЛАВИРИНТ - још једном у складу са постмодернистичком поетиком.

Такође, Фараби-Ибн Кора (исламски представник у хазарској полемици) био је уверен да је његов живот записан у некој књизи (реч је о Запису о путници и школи) и да је у складу са тим и живео (на сличан начин на који се Аврам Бранковић руководио сценама са житејне иконе са чудима Св. Илије пророка). Можда најрадикалнији пример „утекстовљености” ипак представља прича о монаху Лонгину, који се уживљава у Житије Светог Петра Коришког. Није необично, нити је у нескладу са средњовековном поетиком да монаси опонашају живот светаца. Међутим, Павићева постмодернистичка верзија умногоме мења овај топос: Теоктист Никољски ће кришом променити изворни текст житија (уместо пет дана поста уписује педесет), па ће се Лонгин „уживети” у измењену верзију, која ће га одвести у смрт. Овим се Никољски повезује са свим осталим ликовима у Павићевом роману који на себе преузимају улогу бога.

У контексту Хазарског речника метафора кавеза може се довести у везу и са мотивом nanazaja, као главних чувара хазарског језика ${ }^{9}$, на основу чега се успоставља имплицитна веза између словенског и хазарског језика. ${ }^{10}$

\footnotetext{
${ }^{9}$ Принцеза Атех, наиме, папагаје учи својим песмама (које представљају њену верзију „Хазарског речника”); на тај начин одјеци овог језика доспевају и до двадесетовековног слоја.

10 Између ова два језика могу се уочити и друге везе, углавном видљиве кроз имплицитне контрасте, на пример следеће. Ћирило, као творац словенског књижевног језика, и када болестан заборави све језике - никако не заборавља матерњи, док се Хазари на све начине труде да матерњи језик сакрију, забораве и замене га туђим. Даље, циљ припитомљавања словенског језика јесте христијанизација Словена, његова је намена религијска, а његови учитељи религијски мисионари. С друге стране, хазарски језик можемо назвати језиком поезије, будући да он наставља да живи преносећи песме принцезе Атех. Хазарски језик и њен главни чувар, принцеза Атех,
} 
Словенски језик, као непокорна птица, бива припитомљен, затворен у кавез, док се брига о хазарском језику поверава папагајима, као припитомљеним птицама (које, као такве, често обитавају баш у кавезу). Њих ће Атех ослободити да би кроз простор и време могле преносити хазарски језик. При томе, када је словенски језик у питању, одмах се инсистира на вези језика и писма (непокорне птице и кавеза), док се хазарски језик првенствено преноси усменим путем (птичјом песмом).

За папагаје се углавном везује способност гласовне репродукције, механичког понављања, тј. понављања без разумевања (када се за људе жели рећи да некритички понављају туђе мишљење, обично се каже да понављају као папагаји). То је полазна основа од које и ученици могу поћи, на основу свог искуства. Али, шта то понављање може значити у постмодернизму? Лексема nanazaj налази се у наслову постмодерног романа Џ. Барнса Флоберов папагај, који се, занимљиво је, појавио исте године (1984) када и Хазарски речник (уп. Baker 2000: 28). Интерпретација фигуре папагаја у Барнсовом роману коју нуди Џ. Скот (1990) може, донекле, бити илустративна и за Хазарски речник. Према овом аутору (Scott 1990: 67-68), ограничено знање и „ропство” човечанства дискурсу приказани су кроз фигуру папагаја. Пошто папагаји понављају фразе (= дискурсе) које чују дакле дискурсе који су имитативни, инертни, они нису способни да значење припишу било чему ван тога система. Тиме се ствара осећај затворености у клопку знакова из које није могуће побећи у пуну сигурност. Ово тумачење у складу је са постмодернистичким виђењем да је референт увек уписан у дискурс културе, да стварност можемо знати само као произведену и подржану културним представама о њој, те да је представљање прошлости праћено идеолошким импликацијама (Hačion 1996: 200-205).

Један од постмодернистичких топоса јесте сумња у моћ језика да представи стварност (Нас̌ion 1996: 200-201), односно да реферише на било

на још један начин су у дубокој вези са поезијом. Наиме, принцеза Атех ступа у полемику, увек као победник, са представницима званичних религија на хазарском двору, па и у полемику са Ћирилом у Црвеној књизи. То је навело Х. Р. Јауса на уверење да Атех, одузимајући ,догматско оружје” ученим теолозима владајућих религија тиме што за сваког проналази неки нерешив задатак, истовремено заступа и „право поезије да оспори захтев теологије за апсолутношћу - право да се суспендује питање о, у расправи неоткривеној, последњој истини, и да се задовољи провизорним моралом", чиме као да расправу о конфесијама претвара у такмичење између теологије и поезије (Јаус 1997: 250). Најзад, хазарски језик и хазарска писмена у вези су са пројектом хазарског речника / енциклопедије (песме принцезе Атех њена су варијанта „Хазарског речника”!), чији је крајњи циљ анти-религијски, јеретички стварање Адама на земљи од стране човека. Ипак, тема хазарског језика, због ограничености обима, није могла бити детаљније укључена у овај модел. 
шта друго до на себе самог. ${ }^{11}$ Папагај може бити метонимија за овај топос. Папагаји чувају верзију „Хазарског речника” принцезе Атех, као што Хазарски речник М. Павића говори о различитим (реконструисаним) верзијама „хазарских речника” - али се, сем понављања различитих дискурса - испоставља да Хазара, заправо, нема. Они су присутни једино кроз туђи текст, mуђе дискурсе. На последњем часу биће опет речи о томе шта азбука, чувар словенског језика, насупрот папагају, чувару хазарског језика, још може представљати.

За четврти, последњи час на коме се обрађује ова тема, ученици имају задатак да размисле о томе са којим би се аспектима романа разбијање језика и његово поновно лепљење (метафора из Даубманусове приче о настанку ћирилице) могло повезати. Пре свега, треба да покушају да уоче могућу везу ове метафоре са композицијом Хазарског речника.

\section{4. ЧЕТВРТИ НАСТАВНИ ЧАС - ОД КОНЦЕПТУАЛИЗАЦИЈЕ КА ИНТЕРПРЕТАЦИЈИ (2)}

На четвртом наставном часу разматрају се метафоре у Даубманусовој причи о настанку ћирилице (оне метафоре које нису присутне и у параболи о припитомљавању дивљег језика), кроз њену повезаност са композицијом Хазарског речника и поетиком енциклопедичности. Реч је о следећим метафорама:

СЛОВЕНСКИ (ГОВОРНИ) ЈЕЗИК ЈЕ КРЧАГ КОЈИ СЕ МОЖЕ РАЗБИТИ;

ЋИРИЛИЦА ЈЕ КАВЕЗ/ЗАТВОР;

СТВАРАњЕ ЋИРИЛИЦЕ ЈЕ УНОС РАЗБИЈЕНОГ ЈЕЗИКА КРОЗ РЕШЕТКЕ СЛОВА И ЊЕГОВО ЛЕПЉЕЬЕ;

ПЉУВАЧКА СОЛУНСКЕ БРАЋЕ И ГРЧКА ГЛИНА СУ ЛЕПАК ЗА СПАЈАҢЕ КЬИЖЕВНОГ ЈЕЗИКА СЛОВЕНА.

Разбијање може бити метафора фрагментарности света (уп. Татаренко 2013: 191). Фрагментарност је један од најзначајнијих поступака у

\footnotetext{
${ }^{11}$ О томе сам Павић (2005: 19-20) каже: „Замислимо језик као мапу мисли, осећања и сећања човека. Као све мапе, језик је стотинама хиљада пута умањена слика онога што покушава да прикаже. Стотинама хиљада пута сужена слика људских осећања, мисли и сећања. Уз то, сви смо свесни да на тој мапи мора нису слана, реке не теку, планине су равне, а снег на њима није хладан. Уместо оркана и непогода, нацртана је ружа ветрова. Идеална мапа, па и језик као мапа духовног стања и сећања човека, била би ${ }_{[,]}$дакле, само она у размерама један према један. Све остале мапе не успевају да покрију предложак. Тај „остатак” који мапа, у нашем случају језик, не обухвата, јер није у размери 1:1 (о осталом да не говоримо), у наше време попуњавају неке друге, „некњижевне” технологије језичког уметничког дела, да их тако назовемо, али и други домени, који више не спадају у језичку делатност."
} 
постмодерној књижевности. ${ }^{12}$ Лепљење разбијеног језика да би се унео кроз решетке ћирилских слова на метафоричан начин приказује Павићеву поруку читаоцу изречену у Хазарском речнику - да само онај ко на прави начин успе да склопи причу из делова може доћи до истине. Лепљење се врши уз помоћ грчке глине испод Ћирилових и Методијевих табана. Тиме се, метафорички, наглашава значај грчког језика и писма у настанку словенског књижевног језика и азбуке, а у контексту Хазарског речника - на велики значај византијске традиције. Метафоричком сликом глине на табанима сугеришу ce, с једне стране, многобројна путовања (и искуство) Солунске браће, a, с друге стране - наталожене историјске, духовне и културне везе народа и њихових језика, као и свеколика интертекстуалност проистекла из тих веза. Тиме што Браћа и својом пљувачком лепе „крхотине језика” наглашава се и њихов индивидуални допринос и труд.

Дакле, с једне стране, метафора разбијања јесте метафора самог Хазарског речника. Она, међутим, може бити метафора енциклопедизма у постмодерној књижевности, отеловљеног кроз принцип склапања делова у целину (или целине).

Наставник најпре скреће пажњу на значај појма енциклопедичности у књижевности. Тема се може увести кроз досадашња знања ученика о енциклопедијама - од оних класичних до Википедије, са основним питањем: чему енциклопедије служе? Важно је, објашњавајући овај појам, нагласити да је он значајан за све књижевне епохе (тј. да не „припада” само постмодернизму), али посебан нагласак ставити на његов статус у постмодернизму и Хазарском речнику.

Идеал енциклопедизма ${ }^{13}$ као доступности свеколиког људског знања постоји од античких времена. У данашњем смислу идеја енциклопедизма не везује се само за уређене научне лексиконе и речнике, већ и за облике поимања целине света заступљене у митовима, филозофским учењима, средњовековним сумама, научним теоријама, каталозима и регистрима од античког доба до данас. У различитим областима испољавања људског духа енциклопедичност, као интегралистички концепт, не заснива се на једноставном гомилању знања, симбола, слика - него на повезивању појединачних фрагмената у смисаону целину која треба да представи читав универзум и човекову позицију у њему (Петровић 2012). Енциклопедичност се, с једне стране, повезује са идејом тоталитета, заокружености, свеобухватности, какву, на пример, илуструје опис Ахиловог штита у Илијади (или, на жанровском нивоу - еп и роман), а с друге - са отвореношћу,

${ }^{12}$ В. нпр. рад А. Јеркова (1993) - врло индикативног наслова Оквир, рам, пукотина који кроз поетику фрагментарности Кишових дела разматра иманентну поетику романа овог писца. О поетици форме у српском постмодернизму в., између осталог, Татаренко 2013.

${ }^{13}$ У овом раду термине енцииклопедизам и енцииклопедичност третирамо као синониме. 
бескрајношћу, суштинском неизрецивошћу, какве илуструју многобројни спискови (регистри) кроз историју књижевности (Eko 2011). Иако постоји тежња да се епски тоталитет и свеобухватност вежу за Хомеров свет, Библију, или, рецимо, Дантеову Божанствену комедију, док се за епохе од барокног до постмодерног доба везује знатно хаотичније и гротескније гомилање чињеница које често превазилази сваку сувислост, П. Петровић (2012: 44) скреће пажњу да се многи аспекти поетике енциклопедичности не могу сагледати ограничени само контекстом одређене епохе. Како истиче овај аутор, тензија између затворене и отворене форме постоји како у Хомеровој Илијади тако и у делима која обилују хаотичним (бесмисленим) списковима. Енциклопедичности је иманентна тензија између целовитости и заокружености којој тежи књижевна форма и отворености према мноштву значењских односа и композиционих могућности произведених читањем као успостављањем интратекстуалних и интертекстуалних веза (Петровић 2012: 50). У „сукобу” између холистичког захтева за целином и плуралистичког за разликама, енциклопедичност, истиче Петровић (idem: 38), има спасоносну могућност: омогућује да се целина оствари позицијом плуралитета.

Како се Хазарски речник уклапа у идеју о енциклопедизму?

А. Јерков (1996: 127) истиче да се Хазарски речник од дуге историје енциклопедизма разликује по томе што поред енциклопедијске садржине узима и енциклопедијски облик. Некада је хоризонт склапања делова у целину био посредован милошћу откровења (стари век) или историјским процесом (модерно доба). Јерков (idem: 127-128) наставља:

У постмодерном добу [...] енциклопедијска дела уместо истине и историје могу рачунати само на облик текста. Њих не уједињују ни бог или дух, ни разум или историја, њих уједињује речнички принцип низања одредница, сам азбучни редослед. У велику духовну и историјску празнину, у свет лишен утопијске обмане, постмодерна стратегија уместо изасланика било какве трансцеденције шаље сам текст.

Аналогија којом се може затворити ова тема - а њоме се једнако могло и почети - као да се сама намеће: ако се азбучни редослед јавља кохезионим средством у Хазарском речнику (па и у постмодерном добу уопште), онда се стварање словенске азбуке, описано у Црвеној књизи, може посматрати као својеврсна метонимија стварања самог романа. Стварање азбуке аналогно је, дакле, стварању азбучног редоследа као уједињујућег принципа.

Формирани закључак води до следећег проблемског питања: која је уопште сврха азбучног поретка у књижевности? Ученицима је блиско да се азбучним редоследом дају различити спискови (практични спискови, за разлику од књижевних, како би рекао У. Еко): на пример, у телефонском именику, у дневнику, или у енциклопедијама и речницима који нису тематски усмерени. Тиме се добија на неутралности: ниједном члану списка не даје се предност, његово место у „систему” одређено је случајношћу, управо азбучним редоследом. Али какав је смисао таквог поступка у књижевности? 
Део одговора крије се у следећим Павићевим опаскама: тиме што читалац може сам да бира којом одредницом ће почети читање и којим редоследом ће „слагати” причу, књижевно дело се приближава „реверзибилним” уметностима - скулптури, архитектури, сликарству, који „кориснику (реципијенту) омогућују да делу приђе са различитих страна, или да га чак обиђе и осмотри мењајући смер разгледања по сопственом нахођењу" (Павић 2005: 17). Путање читања су, у зависности од изабране комбинације, многоструке. Павић духовито примећује да су компјутерски стручњаци израчунали да постоји око два и по милиона начина читања Хазарског речника. „Тек преко те бројке читалац ће моћи да се врати на нечију већ раније коришћену стазу читања" (idem: 19). Сем читаочевог избора, роман ће се у штампаном издању разликовати у зависности од писма на коме је писан писмо ће, дакле, „одредити” како редослед одредница, тако и његов завршетак (што није занемарљиво, јер ће увек бити читалаца који ће изабрати да књигу прочитају на „традиционалан” начин - од почетка до краја).

Добар део одговора на постављено проблемско питање крије се у Кишовом идеалу књиге, о коме је говорио поводом добијања НИН-ове награде, пре него што је објављен Хазарски речник:

Moj ideal je bio, i ostaje do dana današnjeg, knjiga koja će se moći čitati, osim kao knjiga pri prvom čitanju, još i kao enciklopedija (Bodlerova, i ne samo njegova, omiljena lektira), što će reći: u naglom, u vrtoglavom smenjivanju pojmova, po zakonima slučaja i azbučnog (ili nekog drugog) sleda, gde se jedan za drugim tiskaju imena slavnih ljudi i njihovi životi svedeni na meru nužnosti, životi pesnika, istraživača, političara, revolucionara, lekara, astronoma, itd., bogovski izmešana sa imenima bilja i njihovom latinskom nomenklaturom, s imenima pustinja i peščara, $\mathrm{s}$ imenima bogova antičkih, s imenima predela, s imenima gradova, sa prozom sveta. Uspostaviti među njima analogiju, naći zakone podudarnosti (Kiš 2006: 197, болд - С. М.).

На сродну „аргументацију” наилазимо и код У. Ека, када пореди поетику списка (регистра) у антици са хаотичним списковима карактеристичним за (пост)модерну књижевност (на пример, Џојса или Борхеса):

Kod Džojsa i Borhesa pisac ne pravi spiskove zato što drugačije ne bi znao šta želi da kaže, već iz ljubavi prema preteranom, iz hibrisa i pohlepe za rečima, zbog radosnog nauka o višestrukosti i neograničenom. Spisak postaje način da se iznova pokrene, takoreći da se primerni Tezaurov poziv na gomilanje svojstava kako bi izašli na videlo novi odnosi između udaljenih stvari, i u svakom slučaju da se stave u sumnju oni koje je zdrava pamet prihvatila. Na ovaj način haotični spisak ostaje jedan od načina ovog raspada oblika koji će, svako na svoj način, sprovesti futurizam, kubizam, dadaizam, nadrealizam, ili novi realizam (Eko 2011: 327, болд - С. М.).

Еко подсећа и на сродне идеје барконог писца и теоретичара Тезаура: 
Emanuele Tezauro (Tesauro) predlaže model metafore kao put da se otkriju dotad nepoznati odnosi između poznatih podataka. Reč je o tome da se načini jedan popis poznatih stvari čijim pregledom metaforična mašta može da otkrije nepoznate odnose. Na taj način Tezauro razrađuje ideju o Kategoričkom indeksu, nekoj vrsti golemog rečnika $\mathrm{F}_{[,]} \mathrm{s}$ tim što bi od rečnika imao samo spoljni izgled, s obzirom da je količina svojstava koje izlaže takva da navodi na pomisao kako se ne ograničava samo na ona koja su pomenuta. Sa baroknim zadovoljstvom zbog čudesnog pronalaska on svoj indeks predstavlja kao „tajnu koja je zaista tajna”, rudnik beskrajnih metafora i domišljatih pojmova budući da domišljatost nije ništa drugo do sposobnost da se ,prodre do predmeta koji su, pod vidom raznih kategorija, dobro prikriveni, i međusobno ih uporedi" - drugim rečima, pronaći analogije i sličnosti koje bi inače ostale neprimećene ukoliko bi svaka stvar ostala razvrstana u sopstvenoj kategoriji (Eko 2011: 233, болд - С. М.).

Мотивисање ученика да уочавају аналогије, законе подударности, да откривају неслућене могућности и преиспитују већ успостављене односе што су закључци које кроз наведене цитате сугеришу Тезауро, Еко, Киш - био би идеал каквом сваки методички модел тежи.

\section{5. ЗАКљУЧАК}

У раду смо представили методички модел за обраду теме словенског језика и писма у Хазарском речнику Милорада Павића на додатној настави у средњој школи. Реализација модела замишљена је кроз четири наставна часа, на којима се обрађивана тема представља поступно: полази се од уочавања чињеница о словенском језику и писму у Хазарском речнику (у односу према историји и традицији), затим се разматра начин представљања тих чињеница, да би се на крају прешло на њихову интерпретацију у контексту структуре и поетике Хазарског речника и постмодерне књижевности. У раду су предложени конкретни методички поступци за реализацију модела у вези са интеракцијом наставника и ученика, избором проблемских питања која служе као окосница анализе, могућим начинима анализе и др. Ти поступци треба да омогуће наставу у којој је ученик активан трагалац за знањем, а наставник његов поуздани водич и ослонац. Посебна пажња посвећена је поступцима који подстичу повезивање различитих области - језика, књижевности, историје, културе - а све са циљем да се ученици, у (пост)модерном духу, мотивишу да уочавају нове и проблематизују већ успостављене односе међу различитим појавама. Трудили смо се да представимо модел кроз чију се реализацију „старе” теме (попут историје словенског језика) реактивирају, онеобичавају - можда би у контексту Павићевог романа згодно било рећи чак и реинкарнирају - кроз (пост)модерније теме, а да при томе на добитку буде и старо и ново, а пре свега критичка свест ученика. 


\section{ИЗВОР}

Павић, М. (2012). Хазарски речник: роман-лексикон у 100.000 речи: андрогино издање. Београд: Завод за уџбенике. [Pavić, М. (2012). Hazarski rečnik: roman-leksikon u 100.000 reči: androgino izdanje. Beograd: Zavod za udžbenike.]

\section{ЛИТЕРАТУРА}

Baker, S. (2000). The Postmodern Animal. London: Reaction Books.

Вељковић Станковић, Д. (2011). „Полисемија у настави српског језика методички приступ полисемији у средњој школи". Кьижевност и језик 58/3-4: 277-296. [Veljković Stanković, D. (2011). „Polisemija u nastavi srpskog jezika - metodički pristup polisemiji u srednjoj školi”. Književost i jezik 58/3-4: 277-296]

Грковић-Мејџор, J. (2007). „Настанак и рана историја словенске писмености”, у Списи из историјске лингвистике. Сремски Карловци - Нови Сад: Издавачка књижарница Зорана Стојановића, 415-426. [Grković-Mejdžor, J. (2007). „Nastanak i rana istorija slovenske pismenosti”, u Spisi iz istorijske lingvistike. Sremski Karlovci - Novi Sad: Izdavačka knjižarnica Zorana Stojanovića, 415-426]

Eko, U. (2008). „Postile uz Ime ruže (1983)”, Ime ruže, Beograd: Plato, 505-536.

Eko, U. (2011). Beskrajni spiskovi. Beograd: Plato Books.

Jаус, Х. Р. (1997). „Павићев Хазарски речник”. Къижевност 102/1-2: 245252. [Jaus, H. R. (1997). „Pavićev Hazarski rečnik”. Književnost 102/1-2: 245-252]

Jerkov, A. (1993). „Okvir, ram, pukotina. Imanentna poetika romana Danila Kiša”, u Danilo Kiš između Cetinja i panonskog potopa, ur. Č. Drašković (Cetinje: Narodna biblioteka „Đurđe Crnojević”): 61-85.

Јерков, А. (1996). „Од нове текстуалности до културне поетике” (поговор књизи Заувек и дан више, Сабрана дела М. Павића, књ. 10), Београд: Драганић, 113-180. [Jerkov, А. (1996). „Od nove tekstualnosti do kulturne poetike" (pogovor knjizi Zauvek $i$ dan više, Sabrana dela M. Pavića, knj. 10, Beograd: Draganić, 113-180]

Kiš, D. (2006). Homo poeticus. Beograd: Prosveta.

Klikovac, D. (2004). Metafore u mišljenju i jeziku. Beograd: Biblioteka XX vek.

Lakoff, G. \& Johnson, M. (1980/2003). Metaphors We Live by. Chicago: University of Chicago press.

Николић, С. (2002). Старословенски језик I. Београд: Требник. [Nikolić, S. (2002). Staroslovenski jezik I. Beograd: Trebnik]

Павић, М. (2005). Роман као држава и други огледи. Београд: Плато. [Pavić, M. (2005). Roman kao država i drugi ogledi. Beograd: Plato] 
Петровић, П. (2012). Енциклопедичност као поетички модел романа Растка Петровића (докторска дисертација). Београд: Филолошки факултет Универзитета у Београду. [Petrović, P. (2012). Enciklopedičnost kao poetički model romana Rastka Petrovića (doktorska disertacija). Beograd: Filološki fakultet Univerziteta u Beogradu]

Поповић, М. (1999). „Моравско-панонска мисија Константина и Методија”. Свет речи 9/12: 63-73. [Popović, M. (1999). „Moravsko-panonska misija Konstantina i Metodija". Svet reči 9/12: 63-73]

Popović, T. ( $\left.{ }^{2} 2010\right)$. Rečnik književnih termina. Beograd: Logos Art - Edicija.

Радуловић, О. (2006). „Хазарски речник у контексту српске средњовековне књижевности". Кюижевност и језик 53/3-4: 279-289. [Radulović, O. (2006). „Hazarski rečnik u kontekstu srpske srednjovekovne književnosti”. Književnost i jezik 53/3-4: 279-289]

Станишић, В. (2004). „Старословенска двоазбучност и српска и хрватска редакција старословенског језика”. Српски језик: студије српске и словенске 9/1-2: 383-396. [Stanišić, V. (2004). „Staroslovenska dvoazbučnost i srpska i hrvatska redakcija staroslovenskog jezika”. Srpski jezik: studije srpske i slovenske 9/1-2: 383-396]

Stockwell, P. (2005). Cognitive Poetics: An Introduction. London - New York: Routledge.

Scott, J. B. (1990). „Parrots as Paradigms: Infinite Deferral of Meaning in „Flaubert's Parrot”. A Review of International English literature 21/3: 5768.

Татаренко, А. (2013). Поетика форме у прози српског постмодернизма. Београд: Службени гласник. [Tatarenko, А. (2013). Poetika forme u prozi srpskog postmodernizma. Beograd: Službeni glasnik]

Hačion, L. (1996). Poetika postmodernizma: istorija, teorija, fikcija. Novi Sad: Svetovi.

Stefan Ž. Milosavljević

PhD student of Serbian language (University of Belgrade, Faculty of Philology)

METHODOLOGICAL APPROACH TO THE LANGUAGE AND ALPHABET OF THE EARLY SLAVS IN MILORAD PAVIĆ'S DICTIONARY OF THE KHAZARS IN TEACHING ADDITIONAL CLASSES IN A HIGH SCHOOL

\section{Summary}

In this paper we present a methodological model based on four lessons dedicated to the way the language and alphabet of the early Slavs (= Slavonic language and alphabet) are presented in Milorad Pavić's Dictionary of the Khazars for students of additional classes in a high school. The first lesson is dedicated to the comparison of the way the Slavonic language and alphabet are presented in Dictionary of the Khazars to the facts known from history of language and medieval literature. The second lesson discusses the way Slavonic 
language and alphabet are conceptualized in Pavić's novel using conceptual metaphors to conduct the analysis. The third and the fourth lessons are dedicated to the interpretation of excerpted metahpors according to composition and poetics of Dictionary of the Khazars and postmodernism in general. Throughout the model, instructions to teaching this topics are presented and explained. Using this model, the correlation between students' previous knowledge about history of language and literature and new knowledge about the poetics of postmodernism is achieved. In addition, the implementation of the model provides a correlation between teaching language and teaching literature in high school.

Keywords: language and alphabet of early Slavs, Milorad Pavić, Dictionary of the Khazars, postmodernism, teaching Serbian language, teaching literature, additional classes.

Примљено: 26. 4. 2018.

Прихваћено: 25. 7. 2018. 